\title{
Envisaging Canada in a Disenchanted World: Reflections on Federalism, Nationalism, and Distinctive Indigenous Identity
}

\section{Jean Leclair ${ }^{\star}$}

\begin{abstract}
Ah yes!
The people, always ignorant and dazzled! They come to watch a scene for which they pay,

To see a strange hand risk their destiny.

Victor Hugo (1802-1885)

[Necker] was blamed by the philosophers of the day for not applying, in all its extent, to commerce and finances the system which they wished to impose on the mind. The philosophic fanaticism which proved one of the evils of the Revolution had already begun

to show itself. These men were desirous of attributing to a few principles that absolute power which had hitherto been absorbed by a few individuals; as if the domain of inquiry admitted of restriction or exclusion.
\end{abstract}

Germaine de Staël (1766-1817)

No sooner had I started looking into Aboriginal and treaty rights issues than did I stumble upon the figure of the Trickster. The Trickster is a mythical figure in Indigenous thinking - an incorporeal being that moulds itself into different forms, be it that of a crow, a rabbit, or a flower whose powers are limited by the physical form it embraces. Despite its remarkable powers, the Trickster is not omnipotent.

While this first limitation already warmed me to the Trickster figure, another drawback furthers his charm. Although it is capable of courage, generosity, resourcefulness, and benevolence, the Trickster is also quite capable of blunders, indecision, frivolity, and trickery. Furthermore, it adores having fun at the expense of others, meddling in situations where it is not supposed to be present, and bringing the unexpected to bear on the most carefully thought-out plans. In short, the Trickster is an imperfect being who scoffs at system-makers ("faiseurs de système") and other rigid thinkers who are indifferent to the dense and fluctuating nature of reality.

I have taught law for more than twenty years. I have gradually become convinced that jurists (like myself), political scientists, and philosophers who are interested in federalism and Indigenous issues - whether they themselves are of Indigenous origin or not - do not always take sufficient consideration of the Trickster in their understanding of these matters. Their intellectual constructions lack asperities. No provision is made for the unforeseen. Everything is just too smooth. Above all, these constructions often overestimate or underestimate the capacity of human beings to think by and for themselves.

It is a basic truth that any person who wishes to speak about something at a certain level of generality must have recourse to concepts that simplify or reify reality. Caution should therefore 
be exercised, since any conceptualization necessarily obscures one part of reality and magnifies another. We need to cultivate a healthy suspicion with regards to the notions that we mobilize in our understanding of reality, failing which we risk convincing ourselves that empirical reality yields to our conceptual frameworks in every respect. $^{3}$

My sympathy for the Trickster was born of a dissatisfaction with the limits of concepts such as rights, sovereignty, the social contract, nationalism, and cultural authenticity - all concepts upon which one stumbles constantly if one takes an interest in federalism or issues pertaining to Indigenous governance. The common denominator of all of these notions is their hostility to pluralism and their imposition of a monocular vision of reality, in that they hyperbolize $a$ single aspect of reality, thus oversimplifying the complexity of the very phenomena they are supposed to explain. In truth, if these concepts are that powerful, it is precisely because they offer a "total" explanation of phenomena that are highly multifaceted. ${ }^{4}$

Above all, my dissatisfaction arose from the conception of human beings underpinning such forms of conceptualization. All too frequently, the way in which human beings are represented oscillates between two equally repellent poles. The first pole makes a "rational idiot" of the human being: an idiot, since he is unable to recognize that his rational choices are meaningful exactly because they are configured by a very specific socio-cultural context, one without which the choice of A over B would be totally arbitrary. Human beings do not live in a vacuum. The second pole, on the other hand, considers the human being to be an "irrational idiot": an idiot because he is incapable of extracting himself by means of reason and willpower from the identitary corset fashioned by history and socialization. I am, of course, exaggerating the two positions here, but to a lesser degree than it would appear.

In fact, nobody satisfies either of these models. It stands to reason that we all are fashioned by socialization processes beyond our control. Thus, whether I like it or not, I was born in Quebec into a francophone Roman Catholic family. That said, as rational agents, we can sort out our opinions, behaviours, and convictions. If renouncing what we have for a long time believed to be true entails some painful wrenching, this wrenching is no less possible for that. Conversely, we are always at liberty to embrace new practices, habits, and opinions.

In the discussion that follows, I will first highlight the dangers inherent in submitting the analysis of the Canadian federal phenomenon or the issue of Indigenous governance to a monocular conceptual lens that gives rise to binary conclusions, a prism that does not do justice to the plurality of identitary markers of the members of the Canadian political community - be they English Canadians, French Canadians, Quebeckers, Indigenous, or non-Indigenous people.

In the second part, I would like to demonstrate how a federal line of thinking ("une pensée fédérale") - I would go so far as to say a federal epistemology - would conversely allow for the complexity of our respective individual identities to be revealed, while unveiling at the same time the ratio of power which intervenes in the construction of a given identity. Finally, I will attempt to demonstrate how this renewed understanding of federalism would allow us to grasp the Indigenous issue from a different angle. ${ }^{5}$

\section{The dangers of monocular approaches $^{6}$}

The critical appraisal of federalism that has been undertaken by several Quebec scholars, as well as the opposition of certain Indigenous scholars to the authority of the Canadian government, provides a good example of a monocular epistemology.

A common characteristic of several Quebec and Indigenous scholars is that they describe the relationship between Canada and Quebec, or between Canada and the Indigenous peoples, as 1) a struggle between nations characterized by profound and absolute cultural distinctiveness; and/or 2) as a zero-sum game between two political communities that are mutually exclusive 
because they are equally sovereign, each bearing a watertight and indivisible political authority.

As we will see further on, these perspectives are certainly not completely devoid of truth. Nor do I doubt that nationalism can constitute a remarkably powerful political lever; there is no need to demonstrate its extraordinary capacity to ensure the cohesion of a given group. But, this is not the focus of my present attention. I am more interested in examining the unspoken epistemological premises underpinning what I will call methodological nationalism: in other words, the point of view in terms of which the world is entirely made up of national groups. Such an analysis will enable me to reveal certain normative consequences associated with this epistemological perspective.

Thus will we see, among other things, that the two postures evoked above both presume the existence of a perfectly singular Quebec or Indigenous identitary essence. Moreover, we will be able to observe that concepts such as nation, sovereignty, and rights are poorly suited to the idea of compromise, overlap, or of multiple belongings. Instead, they refer to a universe of oppositions, of conflicts, and of dichotomous distinctions, rendering more difficult the fashioning of solutions which, while admitting the importance of autonomy, aim at cultivating solidarity and interdependence.

Incidentally, even though I will not speak much about it, I would like to emphasize that there is also an English-Canadian version of nationalism, based not so much on a substantial cultural conception as a formal definition of equality. While it typically slumbers due to its majoritarian nature, it raises its head as soon as the will of Quebeckers and Indigenous peoples to retain control over a portion of their community life manifests itself too strongly.

It goes without saying that, in terms of the Indigenous or Québécois ${ }^{7}$ nationalist perspective, there exists but one nation to which a Québécois or an Indigenous community member can belong. As civic, democratic, and open to difference as it may be, a nation has but one centre. We may possibly adhere willingly to the nation; however, we can adhere but to one nation. The latter is a totality to which one belongs and which one cannot leave, unless one leaves it completely. $\mathrm{He}$ who ventures beyond the symbolic national border and harbours multiple allegiances stands to be excluded due to his lack of patriotism, his blindness, his ignorance, or the false consciousness of the colonized from which he suffers.

Moreover, this point of view often represents the nation as a natural organizing principle instead of an artificial construct, as a subjective transcendent entity, one that is both anterior and superior to its individual members. The nation would derive its existence from a quasi-natural historic process that is independent of individual volition. A nation would thus be not so much the fruit borne from multiple, frequently conflicting interactions between its constitutive members over the course of generations, as the product of a set of socialization processes completely beyond the control of individual members. Of course, nationalist writers are not oblivious to the fact that such interactions do take place, but this does not give rise to any consequences that seriously impact their way of thinking. In their view, a person essentially remains largely determined by her cultural and social environment. Her capacity to think by and for herself ( i.e. her agency), is accordingly all the more diminished.

Furthermore, the word "nation," as employed by them, designates society as a whole. In other words, to talk about the Québécois nation or an Indigenous nation is to refer to the entire body of Québécois or Indigenous community members for whom one is talking.

This epistemological perspective, in presuming consubstantiality of nation, society, and state, also has the effect of emphasizing the discourse of those who speak on behalf of such nations (such as politicians or scholars - "those who know"), rather than the point of view of its constitutive members, the latter being conveniently presumed to be unanimous.

Finally, nationalist thinking in its Québécois or Indigenous version relies on a differentialist and totalizing conception of culture. National distinctiveness depends on cultural difference. 
Consequently, everything is cultural and nothing escapes the net cast by this expression; it not only includes that which one spontaneously connects to the idea of culture, but also the world of values. In terms of this worldview, we are all respectively enclosed in universes that are cognitively, culturally, and axiologically opaque to others. Accordingly, that which qualifies as Indigenous culture cannot simultaneously qualify as Canadian or Québécois culture, and vice versa.

Clearly, methodological nationalism renders the idea of federalism practically unthinkable. Where federalism postulates that citizens of a single state may easily harbour a sense of belonging to more than one community, nationalism excludes this possibility. Indeed, the nation is allergic to plural allegiances, since it thrives on exclusivity and unanimity.

Nationalist thinking only ever consents to the idea of federalism in its "multinational" version, as a means of political management of national groups that are conceptualized as being mutually exclusive but "federated" within a shared political space (one, however, that cannot be elevated to the status of "nation"). This perspective appears to me to underestimate the complexity of the identity of these national groups' constitutive members.

Nevertheless, the nationalist perspective contains a great deal of truth. Thus, it is fair to say that Québécois or Aboriginal culture is truly different. But it is most certainly possible to recognize the distinctive, if not unique, character of these cultures without ascribing to them a homogeneity and uniformity of content that they simply do not have. Indeed, if "culture" is understood as comprising the range of concepts and world views that inform the way in which the members of a given community formulate their thinking - something that surpasses a simple linguistic difference - it should not be confounded with a monolith of notions or substantial ideas that are unanimously agreed upon by its members. That culture shapes the way in which a community thinks and expresses itself may well be the case. The notion that a shared culture leads all of a community's members to think the same thing is false. Though they may use identical cultural referents as starting point, they may well end up sustaining profound disagreements among themselves.

Because nationalist thinking assumes too much unanimity between the members of national groups and because it takes the "nation" as a pre-existing given, such thought obscures the role of power in Québécois and Indigenous nation-building, highlighting only that which characterizes Canadian nation-building. ${ }^{8}$ The defunct Charte des valeurs québécoises and the Mohawk community of Kahnawake's membership code offer magnificent examples of iron fisted identitary construction.

Moreover, the cognitive chasm that is said to radically divide Indigenous and "modern Western" thinking is substantially shallower than one might think. Many Indigenous scholars consider that Modernity boils down to the neoliberal agenda, period. In reality, Modernity marks that moment in history (which differs from community to community) where reality is no longer conceptualized as the product of a heteronomous will, external to human beings, and where Tradition and Religion have consequently ceased to play a structuring role in the social and political environment. This is the era of de-transcendentalization of knowledge and power, the era marking a general retreat of the invisible. Henceforth, one may legitimately dissect anything critically. It is an era when social bonds become predominantly political and identity is no longer "given at birth," so to speak. Rather, it is defined and renewed in the course of one's relation to others. Political authority is also no longer accepted at face value: justification is required.

As sociologist Jean-Jacques Simard puts it, Modernity may be understood as:

$[\ldots]$ the age where first the Europeans and then other peoples [...] found themselves at odds with the culture that they had inherited, as if it was something contingent, open to discussion, [...] to choice, while, until that moment, inherited culture precisely and globally defined necessity, both objectively and normatively speaking: an instruction manual for life, a user's guide to the universe, transmittable as 
such from generation to generation as the sole and personal property of each ethnogenetic group. It is then, not that an inauthentic culture - the phrase does not make senses - appeared, but that was raised the insolvable issue of the (spontaneous) authenticity, and (deliberate) inauthenticity, of the relationship of individuals to their Likes, to Others as well as to Themselves. [...] [T] he word 'modern' means nothing more than 'contemporary.'

It goes without saying that criticism preceded the Modern period. Modernity, however, extended it to that which had previously fallen in the domain of the untouchable, the unthinkable.

I am not casting doubt on the holistic and intuitive nature of Indigenous knowledges. Nor am I contesting the intimate bond between these knowledges and the land, or their rootedness in a spiritual matrix. I also recognize that the modes of transmission of these knowledges are not completely aligned with ours. What I object to, however, is the idea that there is unanimity on the content of this knowledge, on the kind of answers to which it may open the door, or on the nature of the values shared by the Indigenous peoples who have access to it. It may well be that there is consensus on a number of things. But, is there unanimity on all? No.

Like other Canadians, the Indigenous peoples of Canada - I am not qualified to comment on the Amazonian Yanomamis - live in a disenchanted world. That is, a world constantly challenged by criticism and exposed to new ideas. Rather ironically, the most ardent defenders of Indigenous tradition are the purest product of the "Modern" thinking that they themselves denounce. By distancing tradition, by objectifying it, by defending it on the basis of perfectly rational and frequently convincing arguments (to Indigenous and non-Indigenous people alike), they embody reflexivity in its most paradigmatic form. And, I emphasize, this does not make of them inauthentic Indigenous persons.

The philosopher Will Kymlicka is not wrong to conclude that a decision is only meaningful if it is based on a horizon of significance shared by the members of a community. However, the horizons of significance ascribed to the Québé- cois and Indigenous societal cultures appear to me to be too stable and too coherent. They are more diverse and fluid than one might think. In addition, I always wonder why Kymlicka never alludes to the possibility that, especially in a federation, one could be immersed, since birth, in two different societal cultures (or three, if one is an Indigenous person). Why should a person be confined to a single such societal culture?

Furthermore, nobody contests the importance of national identity as a marker, but is this to say that it is, at all times and in all circumstances, THE evaluative criterion for the Québécois or the Indigenous peoples? Does an Indigenous or Québécois citizen not make daily choices based on other markers that are as close to his heart (sexual orientation, gender, generational positioning, spirituality, professional identity, ethnicity, aesthetic preferences, etc.)? What right does one have, to paraphrase philosopher Amartya Sen, to "miniaturize the human being"10 to the point of turning him into the standard bearer for a single identitary marker, the national referent? And why may a person not harbour more than one allegiance?

As for the concepts of rights and sovereignty, these also encourage an adversarial approach of the "I win/you lose" variety. Sovereignty is generally conceived of as being unrepealable, incontestable, and indivisible. In the same way that one cannot be semi-virgin, it is difficult to be semi-sovereign. Besides, federalism has always been problematic for theorists of state power. A right, for its part, while very useful on occasion, nonetheless remains a shield brandished to counter or deflect the thrust of one's adversary. It is not a vector of compromise or conciliation. Moreover, the doctrine of Aboriginal rights developed by the Supreme Court of Canada is based on an extremely folkloric conception of Indigenous identity: only cultural activities essential to Indigenous lifestyles as they existed prior to European contact will be afforded protection. This doctrine has certainly opened the door to judicial victories for Indigenous peoples, but it has also fossilized their identity in the warpaints and moccasins of the $17^{\text {th }}$ century. ${ }^{11}$ 
How, then, do we escape from these conceptualizations that induce a dynamic of opposition and conflict that impoverish the debate by ruffling the complexity of our respective identities in binary and simplistic terms, that oblige us to choose between the "authentic" Québécois or Indigenous person and the one who suffers from patriotic anaemia or "cancer of the colon" in the sense of being colonized? By what means can we escape from a conceptualization that considers ambiguity, overlapping, and multiple allegiances to be anomalous?

\section{The possibilities offered by federal thinking ${ }^{12}$}

Any theory needs to base itself on a minimalist anthropology if it is to have a hold on reality. By that, I mean a theory of human nature that fully appreciates what human beings are. In other words, not supermen or superwomen who can effortlessly extricate themselves from real constraints, nor objects of clay wholly modelled by socialization processes.

More specifically, and contrary to monistic understandings of identity, this anthropological perspective requires the recognition that our personal identities are - at least in part - independent from the social element and that a person is capable of putting this element at a distance by way of a rational exercise, and even of contributing to its renewal. This approach does not, however, result in encouraging an asocial or antisocial individualism, for it does not negate the influence of various powers and forces acting on the individual within a society. On the contrary, a person could not develop her individuality outside of a social framework. A person is thus not conceptualized here as an abstract, atomized entity, but as a subject involved in a constant individuation process in the course of which she makes herself - but, with the help of others and not always in opposition to them.

This anthropology also obliges us to admit that some individuals cultivate multiple attachments and that the hierarchical organization of their identitary markers may vary according to the circumstances. The current of our humanity does not flow from a single source. This anthropology also enables us to escape the "'solitarist' approach to human identity" to which methodological holism and methodological nationalism lead: a unifocal understanding of identity according to which "the people of the world can be uniquely categorized according to some singular and overarching system of partitioning." 13 The multiplicity of our allegiances, which does not exclude the possibility that one of them may assume a greater importance than the others, also compels us to recognize that a citizen may consider himself a member of several distinct political communities without necessarily wanting to decide between them.

Federalism, not being a mere descriptive thesis, does not simply acknowledge the existence of these groups to which people attach themselves in various ways, but strives to structure their relationships in order to allow them to coexist peacefully instead of irrevocably breaking with one another. In this structuring, federalism goes beyond simple pluralism, which is sometimes content to observe the existence of differences. Contrary to the concepts of nation, sovereignty, authenticity, and rights, federalism emphasizes the nature of the relations between persons and groups, rather than their essence.

Federalism refers to a duty or rather a moral project that involves at all times combining the "I" with the plural "we(s)" of which we are a part, and this, without necessarily subordinating the one to the other (and vice-versa) under all circumstances. Thus, it recognizes the importance of socialization and the existence of inclusive social formations by attempting to ensure the coexistence of multiple communities within the same unit. It does not, on the other hand, make allowance for the idea of a radical collective singularity that would make a double allegiance impossible. Admitting that an individual unavoidably falls into a social group that surpasses him does not mean that he has to drown in it.

Federalism aims to compel us to conceive of our political future without ever losing sight of the presence and projects of others. By "we" I mean both the citizens themselves and the political entities composed of the federal govern- 
ment, the provinces, and the various Indigenous political groups of Canada. It is in this sense that federalism constitutes an institutionalization of reflexivity. Unlike the concepts of nation, sovereignty, authenticity and rights, it makes the idea of compromise, concessions, even renunciation, plausible.

Moreover, federalism, contrary to the simplistic notion of sovereignty, acknowledges the polycentric nature of power and is not obsessed with what the source of that power is. That is not to say that it is indifferent to issues pertaining to the identity of the holders of such power. But it is not its sole point of interest. It is also attentive to the just or unjust nature of the distribution and exercise of power. Finally, while recognizing that the various orders of government possess political autonomy, federalism's central preoccupation is always the strength of the general frame of reference.

Therefore, federalism is, on the one hand, a political concept that is open to a meaningful recognition of the identitary plurality of individuals and not simply the recognition of a form of "plural monoculturalism." ${ }^{14}$ On the other hand, it is a concept that emphasizes the nature of relations between persons and groups rather than their essence. ${ }^{15}$ This is why federalism has struck me as being a more appropriate route than others for the purposes of reflecting on Indigenous governance. As a concept, it provides a more accurate reflection not only of the malleability of our personal identities, but also of the reality of the relations that have always been maintained between Indigenous and non-Indigenous people in the Canadian political environment. Moreover, and this is of critical importance, the idea of "relations" is at the heart of Indigenous epistemology and ontology. ${ }^{16}$

How does such a conception of federalism assist in elucidating the issue of Indigenous governance? At the very least, it enables us to formulate the question in a different way. Rather than approaching Indigenous governance in terms of colliding rights, nationalisms, and sovereignties, why not instead focus on the type of relations entertained by Indigenous peoples with the Euro-Canadians over time?
From this point of view, that which explains the particular position of Indigenous peoples in the Canadian political order and justifies considering them as constituent actors, is the fact that the relationships maintained by Euro-Canadians with Indigenous peoples were, at all times, based on the notion that the latter were collective actors capable of exercising a political authority. From the time of the very first contact, this political dynamic has generated a particular type of relations between the Indigenous peoples and the Canadian State. Relations that, and this is of the essence, are not simply of historical interest, for they continue to this day. These complex relationships have created expectations, induced actions, and killed off initiatives whose echo still loudly resounds in $21^{\text {st }}$ century Canada.

Whether before or after the advent of the Indian Acts in the middle of the $19^{\text {th }}$ century, the Indigenous peoples have never been considered as simple individual-subjects or individual-citizens, when policies concerning them were developed.

The sheer number of treaties that they concluded with the French and English and Canadian Crowns serve as testimony. Individuals may sign contracts. Only collective political subjects may bind themselves to the terms of treaties. As Chief Justice Marshall of the United States Supreme Court said in 1831 regarding treaties signed with Indigenous peoples: "The words 'treaty' and 'nation' are words of our own language, selected in our diplomatic and legislative proceedings by ourselves, having each a definite and well understood meaning. We have applied them to Indians, as we have applied them to the other nations of the earth. They are applied to all in the same sense." ${ }^{17}$ And the Canadian State has signed, and continues to sign, such treaties with Indigenous peoples.

Even under the regime of the Indian Acts adopted from the 1850s, Indigenous peoples will never be treated as mere individual-subjects or individual-citizens. The imperialist British undertaking and its Canadian successor have always conceived of Indigenous peoples as collectivities capable of exercising political authority, even if it amounted to only delegated 
authority. Admittedly, the hope was to "emancipate" the Indigenous peoples by "civilizing" them, to phrase it in the terminology of the time, but never have laws apprehended them in their sole individual dimension. ${ }^{18}$ It is striking to note that the imperialist Canadian policy has always aimed to keep Indigenous peoples - as political and not just cultural communities - on the fringes of the Euro-Canadian world. The "band," defined as a "body of Indians" by Canadian law, still remains the key political unit in the Indigenous sphere today. And, it is in the band council, designated political mediator of the will of all of its members, that all powers devolved by the law are vested.

To put it in a nutshell, Indigenous peoples have always been perceived by the Euro-Canadian political actors as collective political actors, albeit, from the middle of the $19^{\text {th }}$ century, as second-class collective political actors.

But there is more to it. Our behaviours transform reality and we cannot simply turn a blind eye to their concrete consequences. The signing of treaties, the collective marginalization of Indigenous peoples, and their fierce resistance to their being both physically and culturally eliminated have induced behaviours as well as expectations that we cannot abruptly terminate without causing even more damage.

All these events have contributed to cultivating the Indigenous peoples' desire to self-define as political communities, not so much by claiming a substantially distinctive cultural identity, as by establishing boundaries between themselves and non-Indigenous people. In sum, these events explain why we must still today reckon with Indigenous political communities in the present Canadian political space.

Nevertheless, the (not always involuntary) incorporation of Indigenous peoples in modern society (urban, technological, etc.) has not been without consequences for them. Indigenous identity is now largely, although not completely, dependent on its articulation with the state apparatus and the non-Indigenous population. Completely ignoring this undeniable imbrication would be equivalent to wishful thinking. Of still greater importance, denying the existence of an Indigenous reality henceforth inscribed in a logic that is, at times, different from that of the Indigenous person living in a reserve and away from cities would be an affront to those Indigenous persons who define their identity differently. The Idle No More movement is but the most spectacular manifestation to date of the identitary simmering that is currently shaking up a very diverse Indigenous civil society.

Federalism, from my point of view, requires that we take into consideration the way in which our relationships have structured themselves historically. Among other things, this perspective obliges us to take into account the Indigenous peoples' will to retain a ratio of autonomy that would enable them to "think themselves" ("se penser eux-mêmes"), regardless of where this process may lead them.

However, and in order to avoid falling into the trap of essentialism, I reiterate that we must admit that it is not the content of their difference that matters, so much as does the historic will of the Indigenous peoples, who have not solely been victims, to erect political boundaries mobile as well as porous - between themselves and the non-Indigenous; this same historic will has been shared by the State itself, although, to be sure, the objectives of these oft-conflicting parties have been poles apart.

It follows from the federal perspective expounded here that the Indigenous peoples are entitled to claim a share of political autonomy. The latter is not based on a sovereignty having for centuries lied dormant under the surface of oppression or on a radical cultural difference that is, in any event, too difficult to pin down juridically. Instead, it is based on relations that the Indigenous peoples have always maintained with non-Indigenous people in their capacity as political bodies, and not simply as cultural bodies. Recognizing to Indigenous peoples an autonomous sphere as political bodies and not simply as cultural bodies, whether by treaty or otherwise, means guaranteeing them a constitutionally-protected space within which they will be free, like Quebeckers, to debate among themselves the thorny question of their identity. 
On the other hand, since denying the complexity of contemporary Canadian Indigenous identity would amount to wilful blindness, the federal perspective proposed here is incompatible with any attempt to eliminate shared spaces of political participation and collaboration between Indigenous and non-Indigenous people.

\section{$* * *$}

Such a short piece must necessarily leave unsettled a lot of important questions, a number of which are addressed in the works referred to in the footnotes. However, I wish to conclude by answering the two following questions.

First: in criticizing the monocular approach to which the concepts of rights, sovereignty, and nationalism expose us, do I cling to the hope of seeing them evaporate from the political and legal landscapes? Such hopes seem ridiculous. For better or for worse, these concepts are here to stay. It would be dishonest not to recognize that resorting to rights or to the idea of nation has, at times, enabled the Indigenous peoples to achieve legal and political victories.

The objective of the above exposé on a federalist approach is infinitely more modest. Above all, I attempted to demonstrate that, despite whatever virtues they may have, the above mentioned concepts impose on their adherents a particular way of conceiving the world. One where often the Manichaean logic of "I win/you lose" and of "we/others" is presented as being self-evident, where the presumed homogeneity and unanimity of the nations of which one speaks is not sufficiently questioned, and, where the share of power required for the construction of any nation whatsoever is ignored, such nation never being the pure product of a "natural" historical process. Such a worldview carries normative consequences in that it favours solutions banking on what Amartya Sen calls "solitarism" at the expense of interdependence.

For instance, the recognition of an Aboriginal title can indeed prove a boon to the Indigenous community that succeeds in establishing its existence. However, one needs to admit that the requirement of exclusive occupation developed by the Supreme Court to establish such a title has spoilt the relations between Indigenous communities with overlapping claims. The victory of the one hinges on the defeat of the other. Indeed, the exclusivity criterion incites each community to demonstrate the exclusive character of its own occupation and the occasional and irregular nature of that of its opponent.

As for the mantra of the "nation to nation" discourse, noble as it may be, by making the federal Crown the sole legitimate interlocutor for Indigenous peoples, it delegitimizes all discussions with their closest governmental neighbours, i.e. the municipalities. ${ }^{19}$

If the "epistemology of doubt" that I have attempted to defend in the preceding pages could bring us to recognize that we cannot draw categorical conclusions from ontologically vague concepts (the idea of nation or cultural authenticity, for instance), my efforts would not have been in vain.

Second: besides the introduction of this salutary doubt, is the federal approach proposed here nothing other than an interesting abstraction? I do not think so. It enables us to view federalism in ways different from stato-centric and group-centric perspectives, and allows us to see in it a way of entertaining a relationship with oneself (a "soundless dialogue with oneself") ${ }^{20}$ and with the world. Grasping reality in this fashion also brings with it normative consequences, to the extent that it favors the generation of solutions duly acknowledging our numerous allegiances. Secondly, in my field of constitutional law, the relational approach advocated here would enable the Supreme Court to distance itself from its present essentialist interpretations of Aboriginal rights and thus progressively open the door to the recognition of Indigenous legal orders, and therefore to Indigenous normativity properly so-called. ${ }^{21}$ To recognize such legal orders is to implicitly admit that Indigenous communities are invested with a power of a political nature authorizing them to adopt their own norms, which is the very essence of the idea of autonomy (from the Greek auto and nomos meaning "living by one's own laws"). 
The Supreme Court will soon be forced to reflect on the place to be given to Indigenous legal orders, and hence to the concrete problem of Indigenous governmental autonomy. True, the Court has never recognized even a limited right to self-government to Indigenous peoples. ${ }^{22}$ However, its judges have become entangled in their own conceptual nets. Thus, they have not only recognized that Aboriginal rights and Aboriginal title are collective rights held by Indigenous communities, but they have affirmed that an Aboriginal title comprises "the right to choose to what uses land can be put" 23 and that Aboriginal rights "include the right to determine when fishing will occur and the method and manner of fishing." ${ }^{24}$ Whether the Court likes it or not, the combination of these two elements - collective rights and capacity to make choices - signifies that it has implicitly recognized in Aboriginal rights' holders the power to establish rules and to govern their implementation. The door is, therefore, already partially open for the recognition of a limited form of Indigenous self-government. In a very near future, the Court will no longer be able to conceive of Aboriginal rights as a simple category of land rights. It will need to deal with the issue of the political status of Indigenous actors. A federal perspective might then find favor in its eyes.

I will conclude by emphasizing that federalism quite probably cannot satisfy the existential need for meaning in politics as expected by some, which is to say the institution of a form of power that will restore a meaning to the fact of existing and of having to live together. Because it is based on the idea of compromise, because it is difficult to reconcile with totalizing explanations, one can understand why federalism is not the preferred concept of militants. I am, however, convinced that it could be successfully mobilized to guarantee an autonomous political space for Indigenous peoples in Canada. The only thing the federal theory developed here refuses to admit is that the future is a foregone conclusion and that there is but a single road to follow, or a single voice to be heard. And among those voices, the Trickster's will have to be reckoned with.

\section{Endnotes}

* Jean Leclair, Full Professor, Faculty of Law, Université de Montréal (jean.leclair@umontreal. ca). This text is based on a paper presented in the context of the Conférences Trudeau Lectures, held as part of the Think Big 2015 series organised jointly by the Federation for the Humanities and Social Sciences and the University of Ottawa on June 4, 2015. I would like to express my sincere appreciation to the Trudeau Foundation, not only for the fellowship that it has graciously bestowed upon me, but for presenting me with the opportunity to become part of an extraordinary intellectual community made up of people of all ages, drawn together by their joint interest in themes that Mr. Pierre Elliot Trudeau held dear - he himself having been a former professor of constitutional law at my Faculty. I am grateful to all who have taken the trouble of commenting on the manuscript for this conference. As always, however, the ultimate responsibility for the text remains mine. Furthermore, Elizabeth Steyn and my father Pierre Leclair are to be thanked for their elegant translation of my manuscript and so should NN for her subtle editing proposals.

1 Cromwell, Act V, Scene IX, verses 5428-31: The Dramas of Victor Hugo, vol 19, original work published pre-1945, year unknown; reprint (London: Forgotten Books, 2013) at 410.

2 Considerations on the Principal Events of the French Revolution, ed by Aurelian Craiutu (Indianapolis: Liberty Fund Inc., 2008) at 53-54.

3 See Jean Leclair, "Les périls du totalisme conceptuel en droit et en sciences sociales" (2009) 14:1 Lex Electronica 1. This paper may also be found online: <http://papers.ssrn.com/sol3/papers. cfm?abstract_id=1749523>.

4 See Jean Leclair, "Military Historiography, Warriors and Soldiers: The Normative Impact of Epistemological Choices" forthcoming in Patrick Macklem \& Douglas Sanderson, eds, From Recognition to Reconciliation: Essays on the Constitutional Entrenchment of Aboriginal and Treaty Rights (Toronto: University of Toronto Press 2016) 179. This article may also be found online: <http://papers.ssrn.com/sol3/papers. cfm?abstract_id $=2326486>$.

5 Although he does not situate his thinking in a federalist perspective as I do, John Borrows has 
been defending over the years a thesis bearing a close similarity with the underlying relational perspective proposed in the present article: see, in particular "Landed' Citizenship: An Aboriginal declaration of Independence", chapter six of John Borrows' text Recovering Canada - The Resurgence of Indigenous Law (Toronto: University of Toronto Press, 2002). Some may equally note similarities between the critiques raised here and those enumerated by Alan C. Cairns in his book, Citizens Plus: Aboriginal Peoples and the Canadian State (Vancouver: UBC Press, 2000). My point of view does, however, substantially differ from that of Cairns', to the extent that I am not as deeply concerned as he is by the eventual recognition of an Indigenous political autonomy. Nor do I believe that a canonical preference must be accorded to a pan-Canadian identitary marker in order for the coherence and stability of the country to be assured. Although Cairns never explicitly displays his pan-Canadian nationalism, his preference for the whole at the expense of the parts is always discernible: Alexandra Dobrowolsky \& Richard Devlin, "Citizens Supplicant?: Alan Cairns' Citizens Plus and the Politics of Aboriginal/Constitutional Scholarship" (2002) 7:1 Rev Const Stud 79. By way of proof: having read the book, the reader still has no idea as to what the implementation of the Citizens Plus program would look like. What kind of autonomy does it actually provide to Indigenous peoples? Like others, John Borrows (ibid) and Will Kymlicka (Multicultural Citizenship: A Liberal Theory of Minority Rights (Oxford: Oxford University Press, 1995)) for instance, I think to the contrary that national coherence would be reinforced as opposed to being weakened by the recognition of a true political autonomy for Indigenous communities. That said, I recognize, as does Cairns, the difficulties of all sorts raised by the establishment of the Indigenous political institutions eventually called upon to assume this authority. The road passing from normative discourse to concrete reality will be treacherous. Nevertheless, since in my opinion such recognition will only be implemented gradually, since the Indigenous peoples (except for certain rare exceptions) are not pursuing secession as an objective, and since the scope of the powers claimed will vary vastly from one Indigenous community to another, I do not think that the destabilizing character of attributing them such powers should be exaggerated.

6 All the ideas developed here derive from the texts mentioned in the above footnotes and Jean Leclair,
"Forging a True Federal Spirit: The Repudiation of the Myth of Quebec's 'Radical Difference" in André Pratte, ed, Reconquering Canada: Quebec Federalists Speak Up for Change (Toronto: Douglas \& MacIntyre) 29. This article may also be found online: <http://papers.ssrn.com/sol3/ papers.cfm?abstract_id=1749486>; Jean Leclair, "Le fédéralisme comme refus des monismes nationalistes» in Dimitrios Karmis \& François Rocher, eds, La dynamique confiance/méfiance dans les démocraties multinationales: Le Canada sous l'angle comparatif (Québec: Presses de l'Université Laval, 2012) 209. This article may also be found online: <http://papers.ssrn.com/sol3/papers.cfm? abstract_id=1927356>; English translation due to appear shortly, and Jean Leclair, "Daddy, Is the Sky Higher Than the Ceiling?' Roderick Alexander Macdonald's Federal Epistemology and Ontology" in Richard Janda, Rosalie Jukier \& Daniel Jutras, eds, The Unbounded Level of the Mind: Rod Macdonald's Legal Imagination (Montreal: McGillQueen's University Press, 2015) 63.

7 In the preceding pages, I have referred to the members of Quebec's political community as Quebeckers and used "Quebec" instead of "québécois" as an adjective. However, for reasons that will become obvious, in describing the methodological nationalism espoused by certain scholars in Quebec, I will generally resort to the term Québécois.

8 For more on this subject, see Jean Leclair, "Le rôle de la loi et du pouvoir dans le processus d'accession du Québec à l'indépendance» (2014) 8:1 RDPP 557; an expanded version of this article («Le potier, l'argile et le peuple: le rôle de la loi et du pouvoir dans le processus d'accession du Québec à l'indépendance») was published in Eugénie Brouillet, Patrick Taillon \& Olivier Binette, eds, Un regard québécois sur le droit constitutionnel. Mélanges en l'honneur d'Henri Brun et de Guy Tremblay (Cowansville: Éditions Yvon Blais, 2016) 833.

9 Jean-Jacques Simard, La réduction: L'Autochtone inventé et les Amérindiens d'aujourd'hui (Sillery: Éditions du Septentrion, 2003) at 68 [translated by author]. The original version reads: « ... entendue comme lâge où, les Européens en premier lieu, les autres peuples ensuite, ... se sont trouvés comme placés en décalage par rapport à la culture qu'ils avaient reçue en héritage, comme devant quelque chose de contingent, discutable, ... ouvert aux choix, alors que, jusquà ce moment, la culture héritée définissait précisément et globalement $l a$ nécessité, à la fois objective et normative: un mode 
d'emploi de la vie, un manuel de l'utilisateur de l'univers, transmissibles comme tels de génération en génération et appartenant en propre, exclusivement, à chaque groupe ethnogénétique. C'est alors, non pas quest apparue une culture inauthentique - le terme na pas de sens - , mais que s'est posée la question insoluble de l'authenticité (spontanée), et de l'inauthenticité (réfléchie), du rapport des individus aux Leurs, aux autres et à Soi.... [L]e mot 'moderne' ne veut rien dire d'autre que 'contemporain.»

10 Amartya Sen, Identity and Violence: The Illusion of Destiny (New York: W.W. Norton \& Company, 2006) at xiii, xvi, 185 [Sen, Identity and Violence].

11 See Jean Leclair \& Michel Morin, «Peuples autochtones et droit constitutionnel» in Stéphane Beaulac \& Jean-François Gaudreault-Desbiens, eds, JurisClasseur Québec - Collection Droit public - Droit constitutionnel (Montréal: LexisNexis, 2015) $15 / 1$ at $15 / 132$ (loose-leaf edition); see also Jean Leclair, «Les droits ancestraux en droit constitutionnel canadien: quand l'identitaire chasse le politique» in Alain Beaulieu, Stéphan Gervais \& Martin Papillon, eds, Les Autochtones et le Québec: Des premiers contacts au Plan Nord (Montréal: Les Presses de l'Université de Montréal, 2013) 299.

12 All the ideas developed here derive from the texts mentioned in the above footnotes and Jean Leclair, “Vive le Québec libre!' Liberté(s) et fédéralisme» (2010) 3:1 RNDC 1; Jean Leclair, «Le fédéralisme: un terreau fertile pour gérer un monde incertain» in Ghislain Otis \& Martin Papillon, eds, Fédéralisme et gouvernance autochtone/Federalism and Aboriginal Governance (Québec: Les Presses de l'Université Laval, 2013) 21. Others authors have embraced perspectives bearing some similarities with mine: Dimitios Karmis \& Jocelyn Maclure, "Two escape routes from the paradigm of monistic authenticity: postimperialist and federal perspectives on plural and complex identities" (2001) 24:1 Ethnic and Racial Studies 361; Dimitios Karmis \& Wayne Norman, "The Revival of Federalism in Normative Political Theory" in Dimitios Karmis \& Wayne Norman, eds, Theories of Federalism: A Reader (New York: Palgrave MacMillan, 2005) 1; Tim Schouls, Shifting Boundaries: Aboriginal Identity, Pluralist Theory, and the Politics of Self-Government (Vancouver: University of British Columbia Press, 2003).

13 Sen, Identity and Violence, supra note 10 at xii.

14 Ibid at 156-160.

15 For examples of relational understandings of freedom, sovereignty and self-determination, see
Jennifer Nedelsky, Law's Relations: A Relational Theory of Self, Autonomy, and Law (Oxford: Oxford University Press, 2011); Martin Loughlin, The Idea of Public Law (Oxford: Oxford University Press, 2003); Rauna Kuokkanen, "Aboriginal SelfDetermination: From the Politics of Recognition to Restructuring Relations" (this paper was presented at the ECPR General Conference held in Montréal in August 2015).

16 On the importance of taking into consideration past and present relationships between Indigenous and non-Indigenous peoples, see Susan D. Dion, Braiding Histories. Learning from Aboriginal Peoples' Experiences \& Perspectives (Vancouver: UBC Press, 2009), particularly chapters 6 and 7; on the relational dimension of Indigenous research methodology, see Margaret Kovack, Aboriginal methodologies: Characteristics, conversations, and contexts (Toronto: University of Toronto Press, 2009); Margaret Kovack, "Emerging from the Margins: Aboriginal Methodologies" in Leslie Brown \& Susan Strega, eds, Research as Resistance, Critical, Aboriginal and Anti-Oppressive Approaches (Toronto: Canadian Scholars' Press/ Women's Press, 2005) 19; Shawn Wilson, Research is Ceremony: Indigenous Research Methods (Halifax: Fernwood Publishing, 2008); for a harsh criticism of "Western" research methods and a description of attempts to construct a relational Indigenous methodology, see Linda Tuhiwai Smith, Decolonizing Methodologies, Research and Aboriginal Peoples (Dunedin: University of Otago Press, 2009).

17 Worcester v Georgia, 31 US (6 Pet) 515, at 519 (USSC 1832).

18 The Statement of the Government of Canada on Indian Policy, 1969 (better known as the "White Paper") as submitted by Jean Chrétien in his then capacity as Minister of Indian and North Canadian Affairs, constitutes the sole true attempt to seize the whole Indigenous reality in an almost entirely individualistic perspective. And this is precisely why this policy has been such an utter failure. For an overview of Indigenous reaction to the White Paper, see Kathleen A. van Dalfsen, Nationalization of the Native Voice: The White Paper of 1969 and the Growth of the Modern Native Movement, paper submitted in partial fulfilment of the requirements of the Honours Program in History, University of British Columbia, Okanagan) at 37. This article may be found online: $<$ https://open.library.ubc.ca/ cIRcle/collections/undergraduateresearch/42494/ items/1.0076020>. 
19 For a very interesting plea in favour of establishing a "diplomacy at the local level" between First Nations and municipalities, see Paul Tennant, "Delgamuukw and Diplomacy. First Nations and Municipalities in British Columbia" in Owen Lippert, ed, Beyond the Nass Valley: National Implications of the Supreme Court's Delgamuukw Decision (Vancouver: The Fraser Institute, 2000) 143.

20 Hannah Arendt, "Thinking and Moral Considerations: A Lecture” (1984) 51:1/2 Social Research 7. Arendt writes (at 32-33): “To be sure, when I appear and am seen by others, I am one; otherwise I would be unrecognizable. And so long as I am together with others, barely conscious of myself, I am as I appear to others. We call consciousness (literally, 'to know with myself') the curious fact that in a sense I also am for myself, though I hardly appear to me, which indicate that the Socratic 'being one' is not so unproblematic as it seems; I am not only for others but for myself, and in this latter case I clearly am not just one. A difference is inserted into my Oneness. ... For myself, articulating this being-conscious-of-myself, I am inevitably twoin-one. ... Human consciousness suggests that difference and otherness ... are the very conditions for the existence of man's ego as well. For this ego ... experiences difference in identity precisely when it is not related to the things that appear but only to itself. Without this original split, which Plato later used in his definition of thinking as soundless dialogue ... between me and myself, the two-in-one, which Socrates presupposes in his statement about harmony with myself, would not be possible."

21 On the role of a federal perspective in Canadian constitutional law as it relates to Indigenous issues, see Jean Leclair, "Federal Constitutionalism and Aboriginal Difference” (2006) 31:1 Queen's LJ 521. Under the influence of William Kymlicka's work I then still employed the vocabulary of nationalism. With this reservation, I still consider what I said then as pertinent.

$22 R v$ Pamajewon, [1996] 2 SCR 821 at para 27; also see Delgamuukw v British Columbia, [1997] 3 SCR 1010 at para 170 [Delgamuukw].

23 Delgamuukw, supra note 22 at para 166 [emphasis added]; Tsilhqot'in Nation v British Columbia, 2014 SCC 44 at paras 67, 144, [2014] 2 SCR 257.

$24 R v$ Nikal, [1996] 1 SCR 1013 at paras 88, 106.

25 Delgamuukw, supra note 22, at para 166 [my emphasis] and Tsilhqot'in Nation $v$ British Columbia, 2014 SCC 44 at para 67, 144, [2014] 2 SCR 256. 
